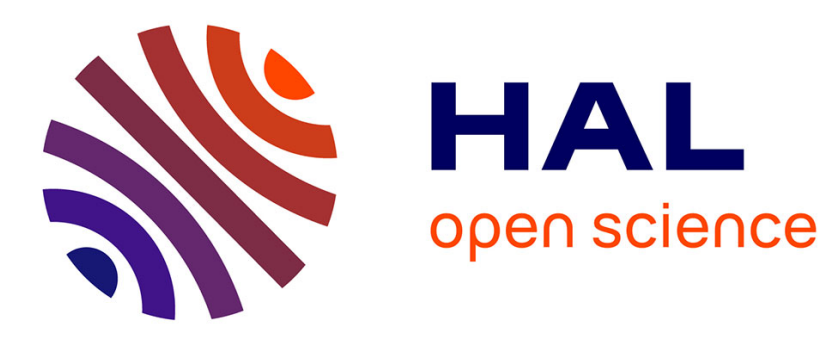

\title{
The epigraphical collection of Museum Ranggawarsita in Semarang (Central Java, Indonesia)
}

\author{
Arlo Griffiths
}

\section{To cite this version:}

Arlo Griffiths. The epigraphical collection of Museum Ranggawarsita in Semarang (Central Java, Indonesia). Bijdragen tot de taal-, land- en volkenkunde / Journal of the Humanities and Social Sciences of Southeast Asia, 2012, Bijdragen tot de Taal-, Land- en Volkenkunde, 168 (4), pp.472-496. halshs-01957963

\section{HAL Id: halshs-01957963 \\ https://shs.hal.science/halshs-01957963}

Submitted on 15 Sep 2020

HAL is a multi-disciplinary open access archive for the deposit and dissemination of scientific research documents, whether they are published or not. The documents may come from teaching and research institutions in France or abroad, or from public or private research centers.
L'archive ouverte pluridisciplinaire HAL, est destinée au dépôt et à la diffusion de documents scientifiques de niveau recherche, publiés ou non, émanant des établissements d'enseignement et de recherche français ou étrangers, des laboratoires publics ou privés. 


\section{ARLO GRIFFITHS \\ The epigraphical collection of Museum Ranggawarsita in Semarang (Central Java, Indonesia)}

Plans for a provincial museum of Central Java were conceived in 1975. The museum was provisionally opened under the fitting name 'Provisional museum', with one exhibition hall (C), in 1983. It inaugurated two more halls (A and B) in 1989, was officially renamed 'Ranggawarsita' in 1990, and reached its present extent with the opening of a fourth hall (D) in $1991 .{ }^{1}$ Besides memorabilia from a more recent past, and a rich collection of 'classical' period stone and bronze sculptures that deserves systematic study, ${ }^{2}$ the Museum also holds a small but significant collection of 'classical' period inscriptions on stone, bronze and gold artefacts. Some of these are still entirely unstudied, others have been published only in inaccessible media, and yet others have been reported when they were still in situ, without any reading or translation being offered. Several belong to the important assemblage of probably seventh-century inscriptions from sites at the Javanese north coast in kabupaten Batang that are of particular importance for understanding the genesis of

1 These details are taken from the Buku Panduan Museum Jawa Tengah Ranggawarsita, compiled by Drs. Sunarto, edited by Drs. Puji Juharnoto, M.Pd, P.Par, and published by the government of the province Central Java (without date), pp. 6-7. The booklet mentions a website www.museum_ronggowarsito.org but this does not seem to exist. I have not found any other proper website for the museum, although at the time of this writing the museum is represented with a Facebook page. I adopt the spelling Ranggawarsita from the cited booklet.

2 By way of example, let me mention just the exquisite sculptures from Candi Ngempon (see Degroot 2009:402, referring to Laporan tahunan 1951-1952, Dinas Purbakala Republik Indonesia / Archaeological Service of Indonesia, Djakarta 1958: Figures 34, 36, 37), the unique sitting Durgā with pendant leg from Candi Gedong Songo (OD 3781), a rare bronze Agastya sculpture, and the nice collection of bronzes from the Rejoso finds (Nugrahani et al. 1998; Hermawati and Kussunartini 1998-99; Sundberg 2004).

ARLO GRIFFITHS is Professor of Southeast Asian History at the École française d'Extrême-Orient, and head of its Jakarta branch. His main fields of academic interest are ancient Southeast Asian history on the basis of inscriptions, and Sanskrit philology. He is the author of (with W.A. Southworth), 'La stèle d'installation de Śrī Ādideveśvara: Une nouvelle inscription de Satyavarman trouvée dans le temple de Hoà Lai et son importance pour l'histoire du Pāṇụranga', Journal Asiatique 299, 2011, pp. 271-317, and 'Inscriptions of Sumatra: Further data on the epigraphy of the Musi and Batang Hari River Basins', Archipel 81, 2011, pp. 139-75. Professor Griffiths may be reached at arlo.griffiths@efeo.net. 
early 'Indianized' polities in Central Java. ${ }^{3}$ With one exception, all the inscriptions that have previously figured in the secondary literature were held at different locations at the time the respective publications appeared. There are thus good reasons to make known which pieces are currently held in Semarang, and to give information about their contents.

I visited Museum Ranggawarsita on 19 August and again on 13-14 September 2011. The Museum's staff, particularly Mrs. Laela Dewi and Mrs. Kussunartini, have shown extraordinary enthusiasm in facilitating my study of the collection that is in their care, not in the last place by allowing me to make the inked estampages (now held in the EFEO library in Paris) that support my readings and are used to illustrate this article. A special word of thanks goes out to these kind persons.

\section{Stone inscriptions}

\section{Inscribed base of Śiva's bull (Figures 1 and 2)}

A rather badly preserved statue of Śiva's Bull (not to be called Nandi), ${ }^{4}$ hewn from a very rough type of stone, with inventory number 04.0040, found in desa Deles, kecamatan Bawang, kabupaten Batang, bears a short inscription on the base at the right flank of the animal. The inscription comprises two lines engraved in archaic letters possibly datable as early as the seventh but no later than the eighth century (note especially the shape of $m a)^{5}$

3 The relevant publications thus far, concerning inscriptions found in Batang regency, are Boechari 1966 (inscription of Sojomerto); Satari et al. 1977:8-10 (inscriptions of Banjaran and Kebondalem = Balekambang); Satari et al. 1978:2 (inscriptions of Banjaran, Blado, Sojomerto); Suhadi and Soekarto 1986:3-7 (inscriptions of Blado and Sojomerto); Atmodjo 1994:4-5 (inscription of Wutit). As far as I know, the Indrokilo inscription (Nakada 1982:88-9) remains unpublished. See also the conclusion of this article.

4 This Bull, universally referred to as Nandi(n) both in scholarly literature and in popular parlance in Indonesia, ought simply to be called 'Bull', until any local sources can be adduced to prove that the animal bore another name in ancient Indonesia, because this (vrșabha and other synonyms of 'bull') is what the classical Indian texts call him. See Bhattacharya 1977 [= 2000:14972] and 1984 [= 2000:173-80]; Sanderson 2003-04:438, note 318; Goodall et al. 2004:100-8. See also Griffiths 2009:475, note 21.

5 In this article, I use the following editorial conventions: graphic elements wholly lost or wholly unreadable on the stone but restorable on the basis of philological considerations are placed in [...]; graphic elements whose reading is visually uncertain but philologically probable are placed in (...); marginally added akșaras are printed between $+\ldots+$; readings that are merely mechanical renderings of what I think I see on the stone are printed in italics; a letter $\mathrm{x}$ represents one totally illegible syllable; a capital letter $\mathrm{C}$ indicates one illegible consonant; a raised circle ${ }^{\circ}$ precedes independent (akșara) vowel signs; the breve sign ( $)^{\prime}$ ) on a vowel explicitly indicates that it is short where a long vowel might be expected. 
(1) namaś śivāya

(2) janmaccheda

The text is not complete. Possibly a part has broken off on this face of the pedestal, or the text may originally have been continued on another face which would have suffered such damage that the continuation of the text is no longer visible there. One expects something like janmaccheda[kāranāaya], ${ }^{6}$ which would allow translating the whole as 'Homage to Śiva, Cause of the cessation of rebirth'. I have not found any publication referring to this statue or its inscription.

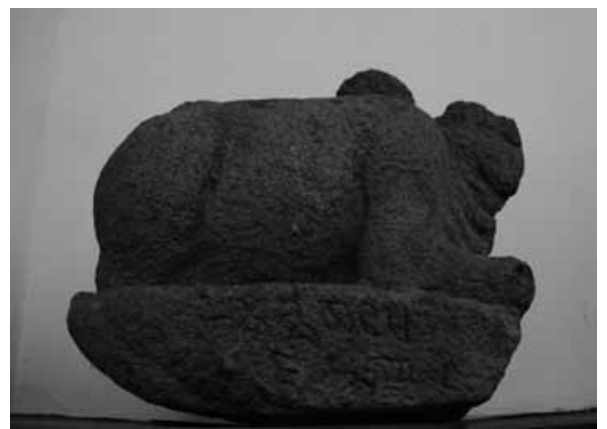

Figure 1. MRS 04.0040. Śiva's Bull. Photo Véronique Degroot.

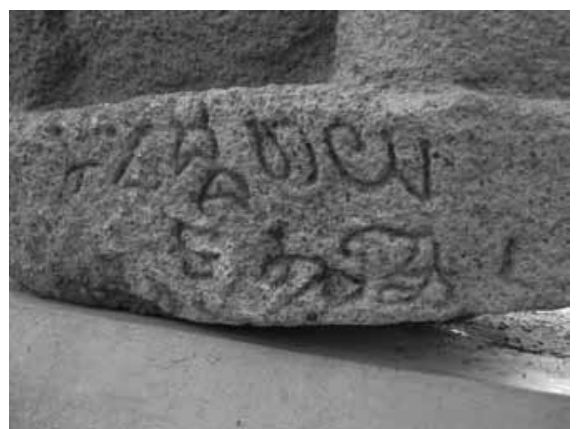

Figure 2. MRS 04.0040. Inscription on the base. Photo Arlo Griffiths.

\section{Balekambang stone inscription (Figures 3 and 4)}

Two blocks of stone, forming the upper and lower fragment of one original roughly hewn stela in andesite, bear the inventory number 04.0076. The existence of this inscription seems to have been first reported by Satari et al. (1977:10, §B.5.1a and p. 32, photo 20). Their photo shows the inscription, already cracked (but the parts are joined together) when it was still in situ. They recorded as administrative divisions dukuh Bendosari, desa Kebondalem, kecamatan Gringsing, kabupaten Batang, Central Java. The inscription was found at $100 \mathrm{~m}$ from a pond called Balekambang where several sculptures and traces of a structure were also found. This site nowadays falls in the desa Sidorejo. ${ }^{7} \mathrm{~A}$ recent publication has given it the appropriate name 'Prasasti Balekambang'

6 Alexis Sanderson has commented that -cheda is odd Sanskrit, that he finds no parallels, and would expect -uccheda. He cites such expressions as samsārocchedanam, prajocchedah, sarvocchedah, kulocchedah, svavamśsocchedah, mülocchedah, samtānocchedah. Nevertheless, the reading is beyond doubt.

7 Information from Véronique Degroot, who has visited the site, and noted these coordinates: $06^{\circ} 56^{\prime} 41.5 \mathrm{~S}, 110^{\circ} 00^{\prime} 37.0 \mathrm{E}$. 
(Noerwidi 2007:68, 70). In one piece, the dimensions of the stone are $85 \times 44 \times$ $32 \mathrm{~cm}$. The inscription is composed in Sanskrit and seems to comprise a stanza in the $\bar{a} r y \bar{a}$ meter. ${ }^{8}$ This hypothesis underlies my attempt at restoration of this badly worn and fractured inscription. ${ }^{9}$

(1) [ ${ }^{\circ}$ a]yam anatibāhuvīryya(2)s sphațikamaṇinibha(3)ñ (j)ala(ṃ) prathi(tavā)n ya(ḥ)

(4) tasya $\mathrm{Ci} \sim-\sim$ nāmnah ${ }^{10}$ (5) jīvitam etac cira(m bhava)tu

'May this life (on earth) be long for this man the strength of whose arms is unsurpassed, who has revealed the crystal-clear water, ... by name!'

The structure, with a genitive ending in ${ }^{\circ}$ namnah governed by jīvitam as subject and ciram as predicate with the imperative verb form bhavatu, is strikingly reminiscent of the textual structure of the Plumpungan/Hampran inscription, situated in dukuh Plumpungan, desa Kauman Kidul, kecamatan Sidorejo, kotamadya Salatiga, at about $65 \mathrm{~km}$ SE from Balekambang, as the crow flies, or about $80 \mathrm{~km}$ if one follows the coast and approaches Plumpungan by the easiest route. In $p \bar{a} d a s \mathrm{a}+\mathrm{d}$ of the Plumpungan inscription we find the same words literally or in synonym (bhavatu jivitam nityam), but with several additions: dharmmārtham kṣetradānam yad udayajananam yo dadātīśabhaktyā ... tasyaitad bhānunāmno (bh)uvi bhavatu yaśo jīvitam caiva nityam. 'Eternal on earth may be the fame and the life of him called Bhānu who, for the sake of dharma, out of devotion for İ́a (Śiva), gives this donation of arable land, to promote prosperity ...'. This last inscription is datable to $750 \mathrm{CE}$, if we may follow Damais, ${ }^{11}$ and is composed in an early form of the cursive form of writing, which scholars are used to calling 'Kawi' or 'Old Javanese' script. ${ }^{12}$ The present inscription is,

8 On the use of this meter in Indonesia, almost only attested in epigraphy (and, with the exception of the Kakavin Rāmāyana, not in any Old Javanese poem using Indian meters), see Poerbatjaraka 1932:177-8.

9 Especially the restoration of the first syllable in [ ${ }^{\circ}$ a ${ }^{2}$ yam: the hypothetical first akșara has been completely lost with what seems to be a part of the corner of the stone broken off, but it is not at first sight evident that the stone has suffered damage here. Dominic Goodall, Alexis Sanderson and Yuko Yokochi have provided vital criticism of my various attempts along the way to the result presented here.

10 The fracture of the stone here has brought about the nearly complete loss of the consonant sign on top of which the $i$ vocalization is still perfectly visible, and with it both of the immediately following akșaras; the third clearly comprised a consonant cluster (rendering the preceding syllable metrically heavy), but I am unable to make out what it was. It seems impossible to propose with certainty a restoration for the name that was once written between tasya and ${ }^{\circ}$ nammah, but it cannot have been the same (Bhānu) as in the Plumpungan/Hampran inscription.

11 Damais 1952:20-1, 1955:247-8, 1968:309.

12 The only published reproduction of this inscription that I am aware of covers only a small part of the text, but is enough to illustrate the palaeographic difference from the Balekambang inscription: see Suhadi and Soekarto 1986:23, photo 6 [printed upside-down]. 


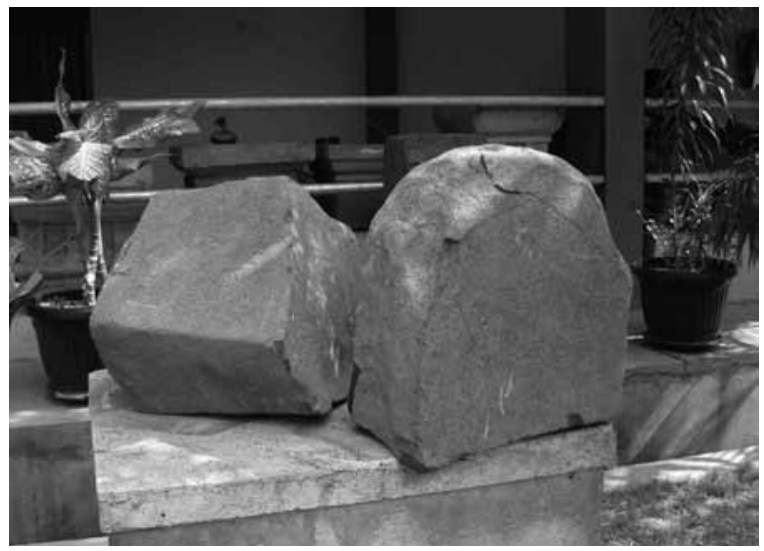

Figure 3. MRS 04.0076. The two fragments of the Balekambang inscription as exhibited in 2011. Photo Arlo Griffiths.

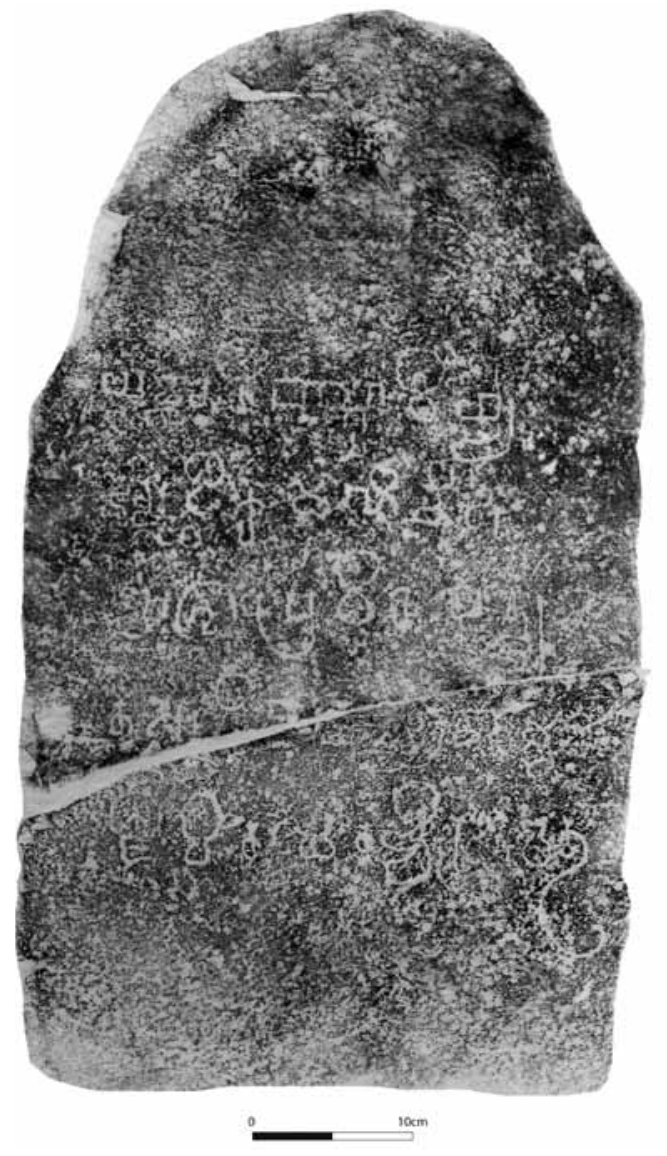

Figure 4. Balekambang inscription. Composition of the two EFEO estampages n. 2040 and n. 2039. 
however, engraved in the stiffer script that is usually called '(late) Pallawa', and is not seen in Indonesia after the Canggal inscription of 732 CE. The present inscription would seem to be older than the Canggal inscription, for the descenders of the test letters $k a$ and $r a$ are still extended far below the base line, where they form a loop, and the shape of $l a$ is also markedly more archaic here. I estimate the Balekambang inscription to date from the second half of the seventh century.

\section{Block of stone (Figures 5 and 6)}

A rough block of andesite stone with the inventory number 04.1135, apparently found in kecamatan Tuntang, kabupaten Semarang, and apparently not mentioned in the previous scholarly literature, seems to represent only a part of an original larger boulder. It bears an inscription of one line, which seems to compremise the beginning of a dating formula which would have been completed on the part of the stone that is not available:

\section{śrī $685^{\circ}$ asuji}

For lack of comparably early numeral signs, ${ }^{13}$ the reading of the figure for the units is uncertain, but could hardly be anything else than 5 . The unexpressed era must be Śaka. This means that we are dealing with the third oldest dated inscription of Java, after the inscriptions of Canggal, Plumpungan and Dinaya (respectively of 654, 672 and 682 Saka, that is 732, 750 and $760 \mathrm{CE}$ ), and the last dated stone inscription in 'Kawi' script before the Kamalagi (Kuburan Candi) inscription of 743 Śaka (821 CE) terminates a long gap of more than 50 years without dated stone inscriptions.

Although the linguistic material comprised in this text is minimal, the month-name asuji is enough to determine the language as non-Sanskrit, and almost certainly Old Javanese. ${ }^{14}$ This determination yields us now an inscription that is 41 years older than what was just far considered the oldest inscription in Old Javanese, viz. the Sukabumi (Harinjing A) inscription which is a later copy of a text first issued in 726 Śaka $(804 \mathrm{CE})$. The first original Old Javanese text was thus far that of the Munduan inscription issued in 728 Śaka $(807 \mathrm{CE}){ }^{15}$

13 Compare Damais' 'Tableau comparatif des chiffres indonésiens à partir du vir siècle śaka', appended to his 1952 study. The earliest signs for 5 included in the table date respectively from 764 and 776 Śaka.

14 On the month name asuji, see Damais 1951:11-2: 'Il est à noter que le Sanskrit açvina n'est jamais employé dans les inscriptions rédigées dans une langue indonésienne. On ne recontre que Asuji, forme inconnue en Inde.' If one may read ${ }^{\circ} \bar{\imath}$ instead of śr $\bar{\imath}$, one obtains a variant of the Old Javanese preposition $(r) i$, and the language is determined with absolutely certainty.

15 Compare Nakada 1982:74-5; edited in Nakada 1986. 


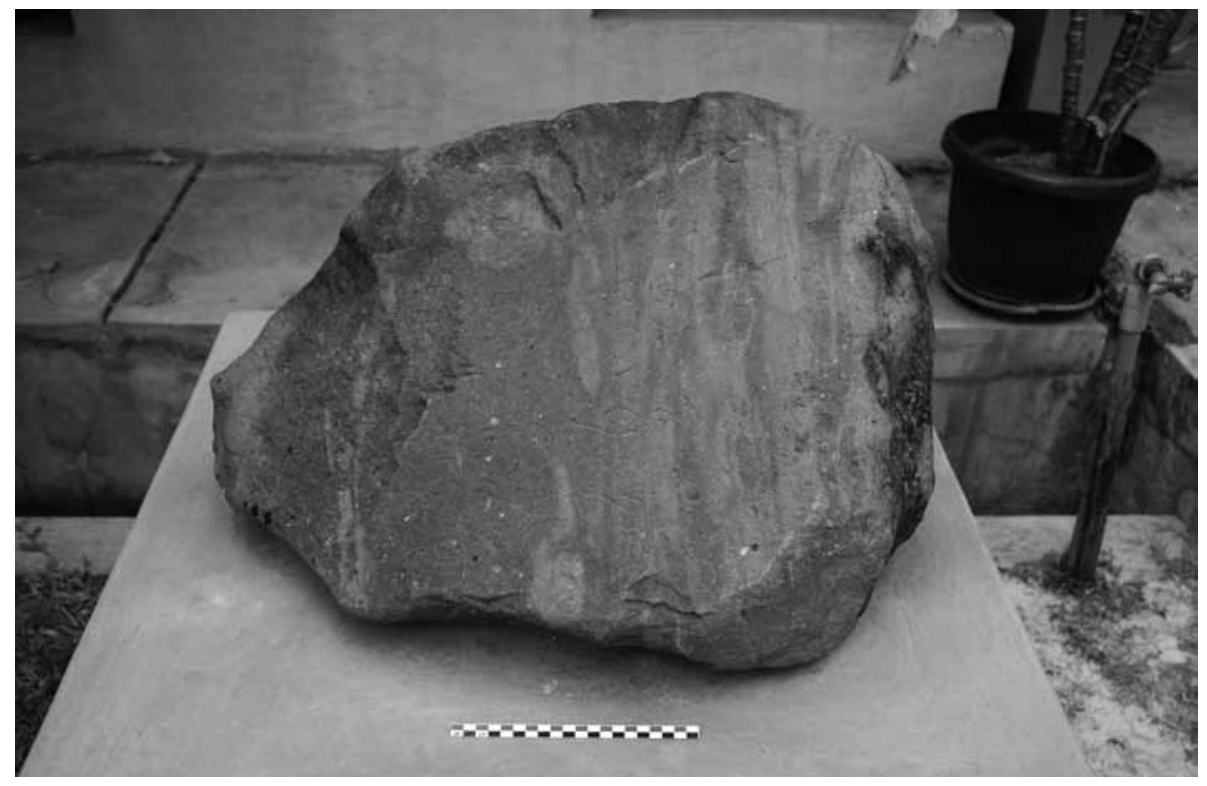

Figure 5. MRS 04.1135. Inscription of 685 Śaka. Photo Véronique Degroot.

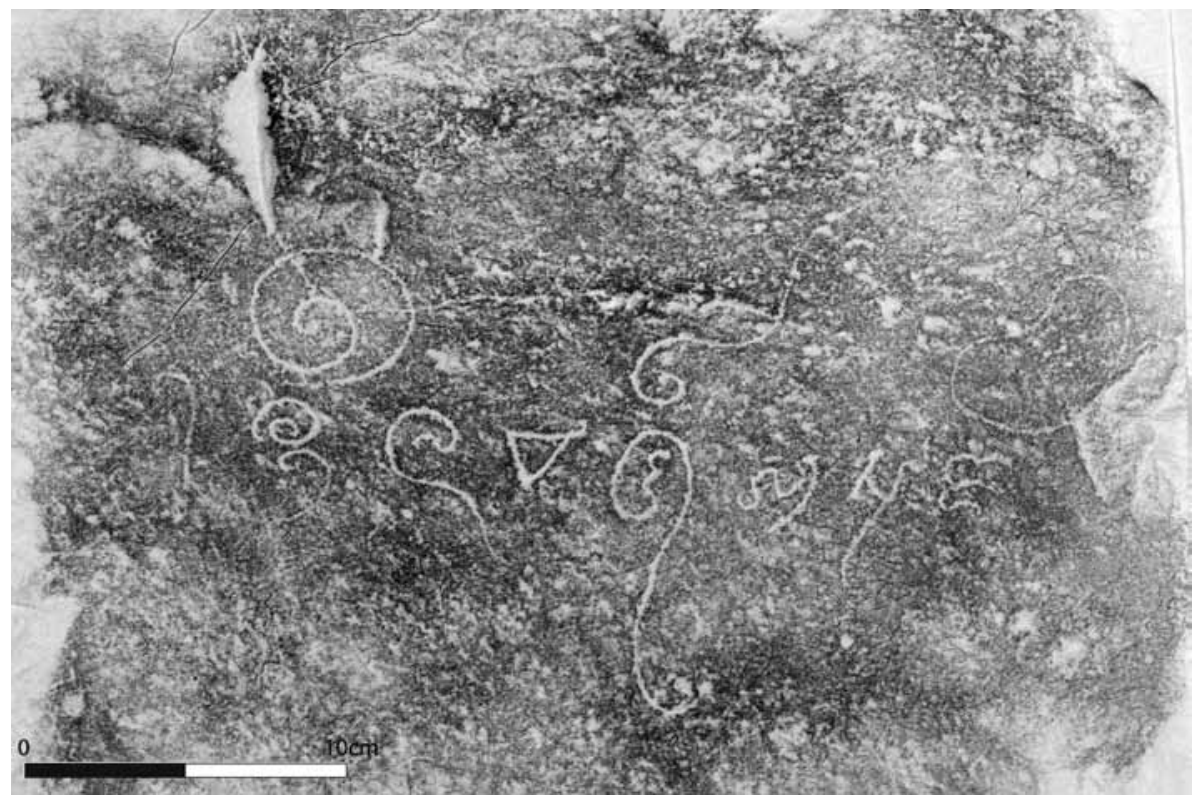

Figure 6. Inscription of 685 Śaka. EFEO estampage n. 2031. 


\section{Banjaran stone inscription (Figures 7 and 8)}

The roughly hewn pillar in reddish stone bearing inventory number 04.0078 was first reported by Satari et al. (1977:8, §B3.1, and p. 30, foto 15). They observed it when it was still in situ, in the middle of a coffee plantation in $d u k u h$ Banjaran, desa Semampir, kecamatan Reban, kabupaten Batang, Central Java. The stone is very worn, so that not a single word can be made out with certainty, and the language cannot be determined either. The execution of the writing seems to have been sloppy to begin with. It is reminiscent of the Kepokoh (Blado) inscription, which Machi Suhadi and M.M. Soekarto (1986:3) have dated to around $700 \mathrm{CE} .{ }^{16}$ But after inspection of that inscription in April 2012, and on the basis of an estampage made at that time, I myself see no strong reason to date the Kepokoh inscription so early, and would be inclined to estimate a date around $800 \mathrm{CE}$ for both the Banjaran and the Kepokoh inscription, if not even later.
(1) ... ya
(2) sarīa $\mathrm{x}^{\circ} \mathrm{um}{ }^{\circ}$ evuvu
(3) jñisūryyada $x x$ ryyala
(4) śaktibhi xxx yaḍa
(5) kapuh $x{ }^{\circ}$ ijicam $x x$
(6) līmariapadrakamañūram
(7) śi $x / / 0$ // śrīvipame
(9) $x x$ habra $x x x$
(10) ...
(11) $\times \mathrm{ki}$...
(12) sva $x x$ pu $x x x x$
(13) $x / / x$

16 The reading they have published is unreliable. The language is certainly not Sanskrit, contrary to the claim of these authors. I hope to publish it at a later occasion. 


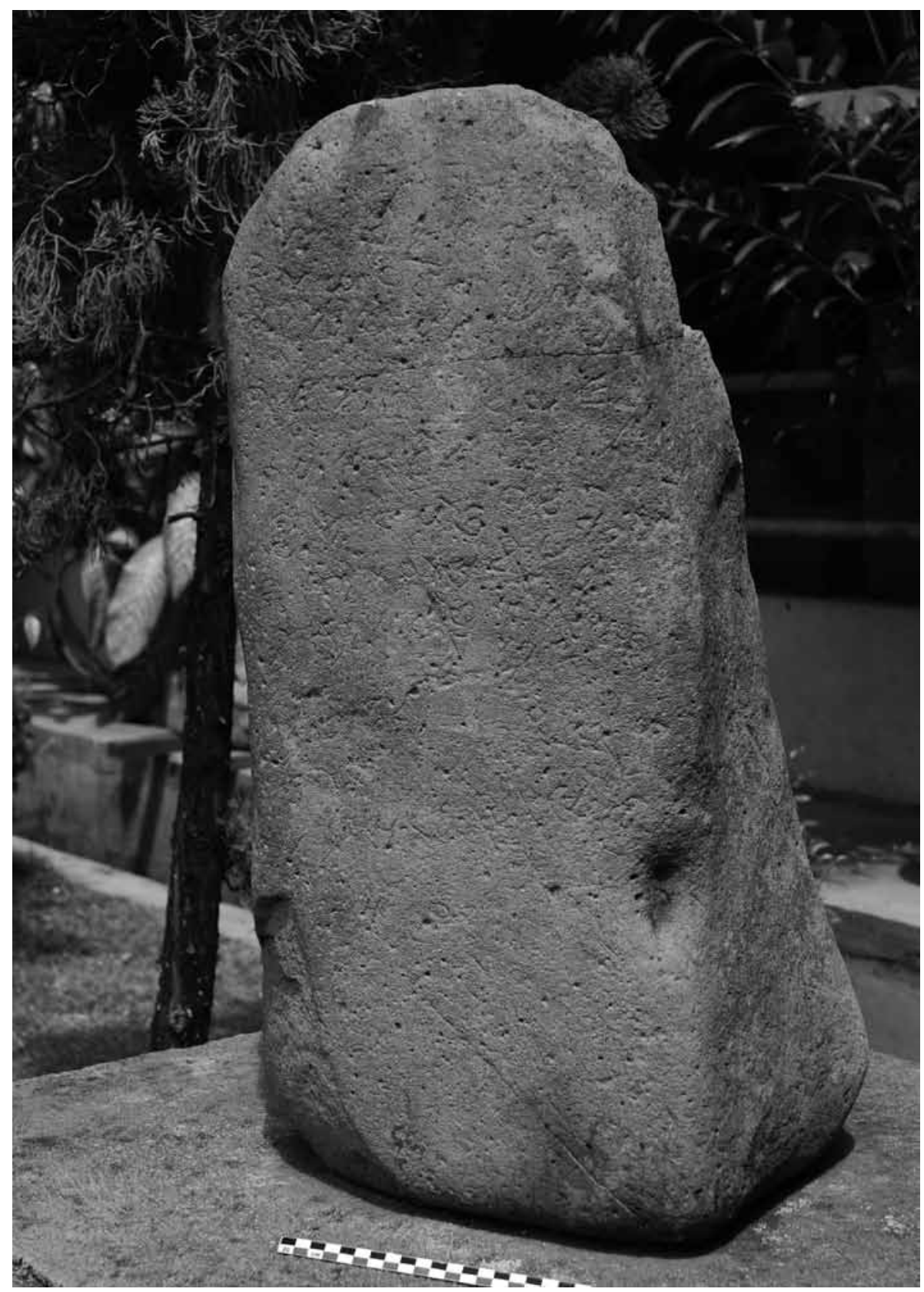

Figure 7. MRS 04.0078. Banjaran inscription. Photo Véronique Degroot. 


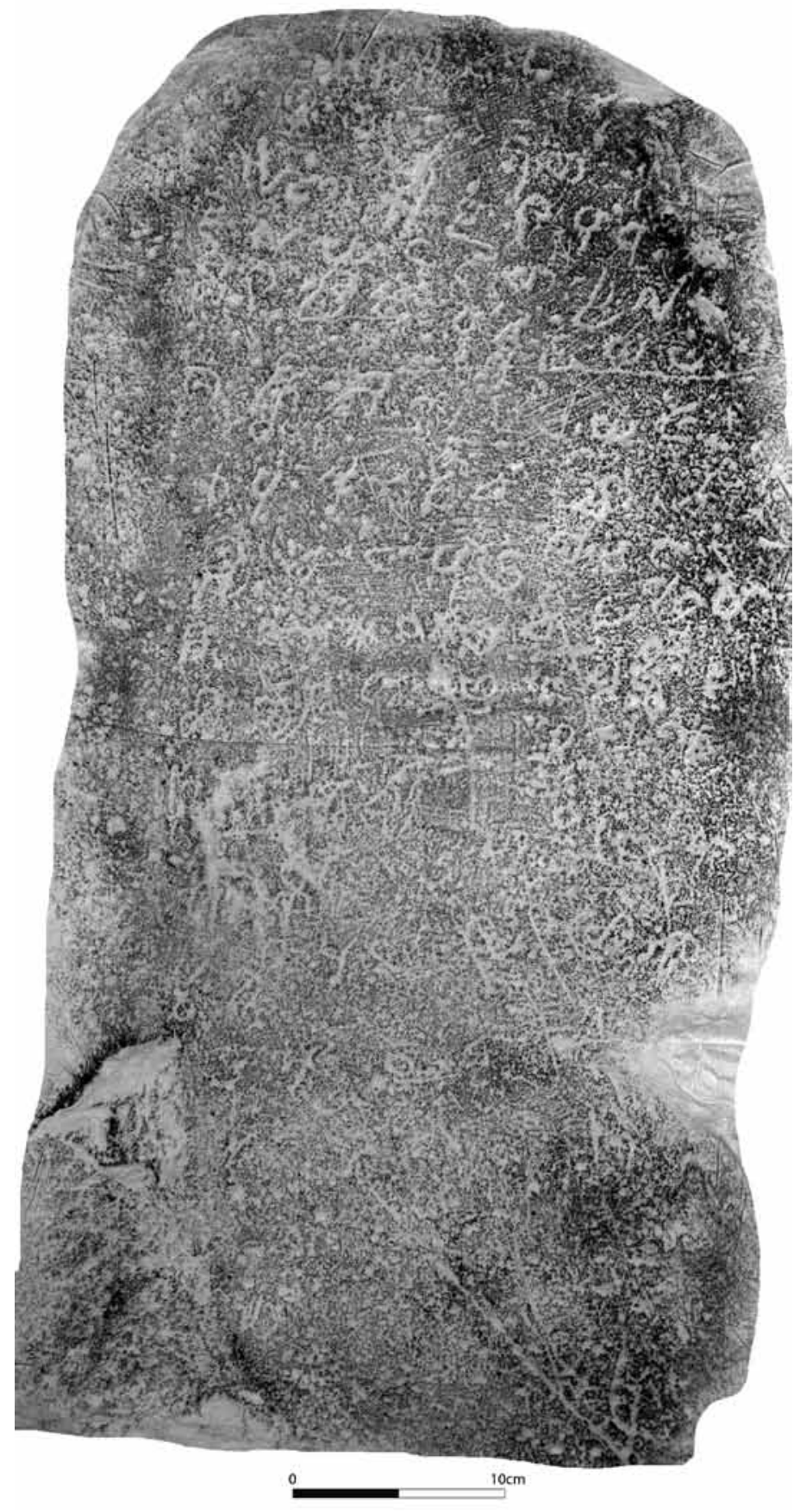

Figure 8. Banjaran inscription. EFEO estampage n. 2034. 


\section{Roughly hewn small pillar of andesite (Figures 9 and 10)}

The andesite stone with inventory number 04.0493, found near the graveyard of dukuh Tlasri, desa Giyanti, kecamatan Temanggung, kabupaten Temanggung, bears an inscription on one face, which has been flattened and provided with a frame wherein a text of nine lines has been engraved. The dimensions of the stone are roughly $66 \times 41 \times 38 \mathrm{~cm}$. Its text has been published by Sukarto K. Atmodjo (1985:233-5), who admitted about his work (p. 231): 'I should explain at the outset that the transcription as well as the translation below need to be studied again. [...] I hope that other specialists in the future will have more success and will be able to give a complete and final explanation. ${ }^{17}$ His reading is without any diacritics, and does not distinguish aspirated from unaspirated consonants. While I cannot claim to be able to make any final statement about this inscription, it seems potentially useful to publish it again here.
(1) // svasti śa+ka+varṣătīta 78[6]
(2) `āṣāọhamāsa pañcamĭ kṛ̣ṇapa-
(3) kṣa paniru ${ }^{\circ}$ an vage budhavāra
(4) `uttarāṣāḍhanakṣatra saubhā-
(5) gyayoga tatkāla pitāma[ha $\left.{ }^{\circ} \mathrm{i}\right]$
(6) vamikud· manusuk sīma ${ }^{\circ} \mathrm{i}\left[{ }^{\circ}\right.$ asa-]
(7) p pañjam vatak pikatan· sam [pa-]
(8) (mga)t $\cdot$ mavanu $^{\circ} a^{\circ}$ irika $x x$
(9) $x$ manukū ${ }^{\circ}$ anak vanu ${ }^{\circ} a{ }^{\circ} i x x$

Variant readings per line

1 78[6]: 786 Sukarto (n. 35: “Angka 6 agak mirip angka 5, sehingga semula saya membaca 785 "). $-{ }^{6}$ vamkud: wankud Sukarto. The reading of the $k$ and $d$ are hard to make out, but Sukarto's guess finds support in the existence of the same name in another inscription (Damais 1970: 694, see my n. 18 below). His $n$ must be for $n$, which Sukarto does not distinguish from anusvāra (m). $-{ }^{\circ}$ irika $x x$ : irikanan .. (dua huruf pecah) Sukarto. The $n$ is again for $m$.

\section{Translation}

Hail! Elapsed Śaka-year 786, month of Āṣạdha, fifth of the waning fortnight, Paniruan, Wage, Wednesday, lunar mansion Uttarāṣạ̄̂ha, conjunction Saubhāgya. At that time the venerable one (pitāmaha) ${ }^{18}$ of Wangkud planted

17 My translation from the Indonesian: 'terlebih dahulu perlu saya jelaskan bahwa alih-aksara (transkripsi) maupun alih bahasa (terjemahan) di bawah nanti masih perlu diteliti kembali [...] Harapan saya mudah-mudahan para ahli lainnya di kemudian hari lebih berhasil dan mampu memberikan penjelasan menyeluruh dan tuntas (final).'

18 On the title pitāmaha (attested in several relatively old inscriptions of the Dieng plateau, but not only there), see Krom 1924:214. In the Dieng inscription OJO XCIX (1. 11), we find a guru hyain 
the boundary markers for Asam Panjang, district of Pikatan. The apanageholding (mavanua) Sang Pamgat was ... Manuku, native of the village ... .

Date

The last digit of the year is unreadable. J.C. Eade has informed me (email of 21/09/2011) that the only option for reading the year is with 6 in the place of the units, so 786, although even in this year the nakșatra on the given date is Uttarabhadrapada, not Uttarāṣādha, and the yoga is Atigaṇda, not Saubhāgya. Eade explains: 'A match of 21: Uttarāṣāḍha with 4: Saubhāgya would require the month to be Bhadrapada around 10-11 waxing. And it is a mix up that has to give way to the consistency of the other data. You can, if so minded, expand what these two rogue elements are saying: Uttarāṣạdha says that the moon is at about 266 degrees and Saubhāgya says that the sun and moon combined total about 40 degrees. This means that the sun component in the sum is about 135 degrees. And if the sun is at about Leo 15 the time of year is somewhere early in Bhadrapada, two months after Āsāạha; and then, if the sun-moon distance is 131 degrees, at 12 degrees/day this is about 11 waxing and not 5 waning: so the nakșatra/yoga combination as given cannot be correct for the time of year.' The result of Eade's conversion of the date is Wednesday June 28,864 CE. $^{19}$

\section{The toponym Asam Panjang}

It will be noted that the text actually points to Asap Panjang, only the $-p$ of the former element actually being preserved. No place name Asap Panjang - or any other other place name ending in ${ }^{\circ} \mathrm{p}$ Panjang for that matter - is known anywhere, whereas Asam Panjang is attested several times (see Damais 1970: 104). It must be noted that the attested spellings of this toponym are quite diverse, and previous scholars have not hesitated to correct other erroneous spellings (asammañjam, sasāpampañjang, see Sarkar 1972:16 note 10, 25 note 17).

\section{Boundary marking linga}

The boundary marker bearing inventory number 04.0546 was published by Atmodjo (alias M.M. Soekarto) in 1994 as 'Prasasti Sang Pamgat Swang'. Titi Surti Nastiti has discovered that another pillar exists with precisely the same text on it, in the Museum Karmawibhangga at Borobudur, and will publish an article about both stones. An estampage of the inscription at Semarang, executed in two sheets, has entered the EFEO collection under numbers n. 2035 and 2036.

i vainkud besides (as witness) a pitamaha i hladan (see Brandes 1913:229, integrally copied in Sarkar 1972:266-7).

19 It can be independently verified by using the HIC and Pancanga programs listed at <http:// indology.info/links/soft/>. 


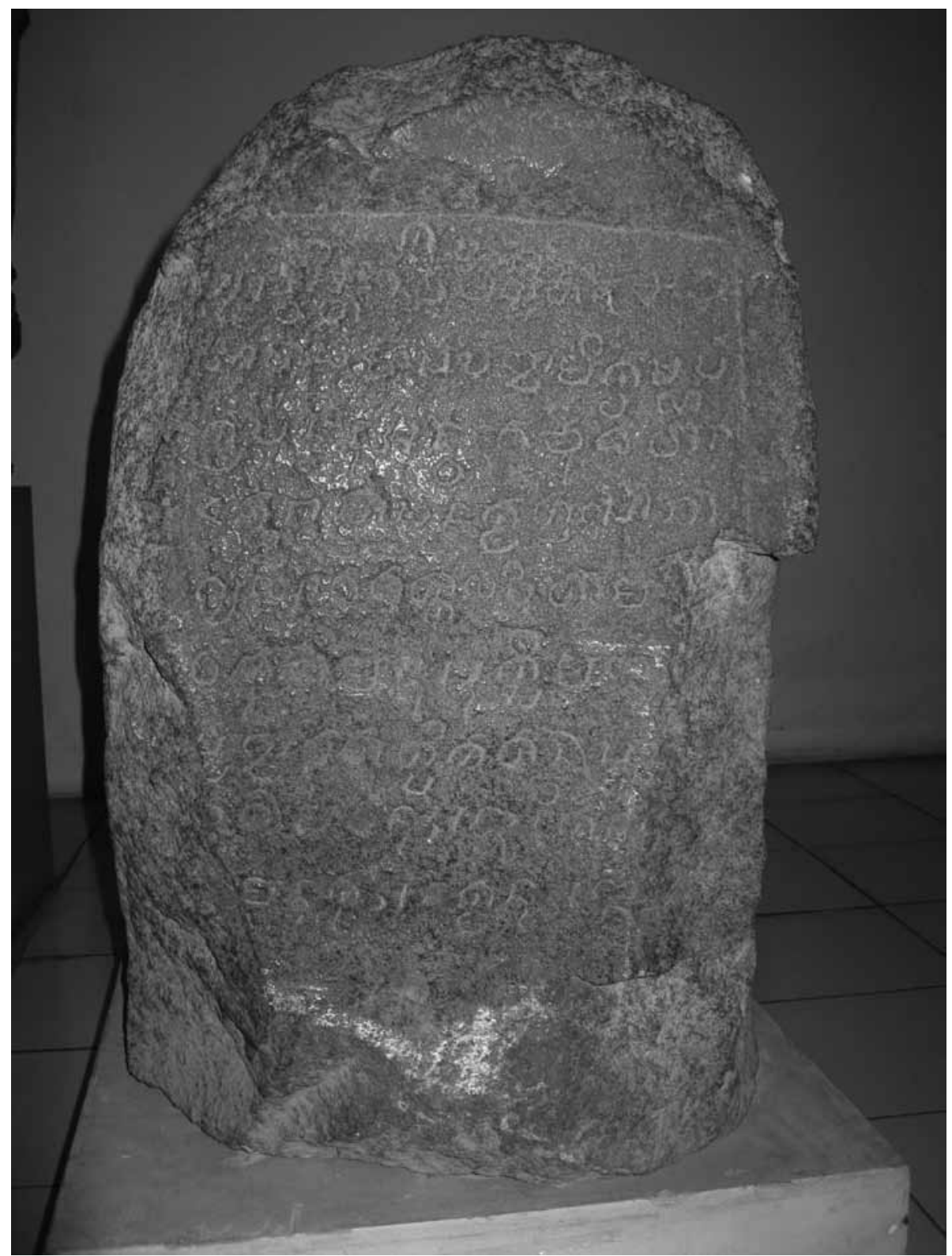

Figure 9. MRS 04.0493. Wangkud inscription. Photo Arlo Griffiths. 


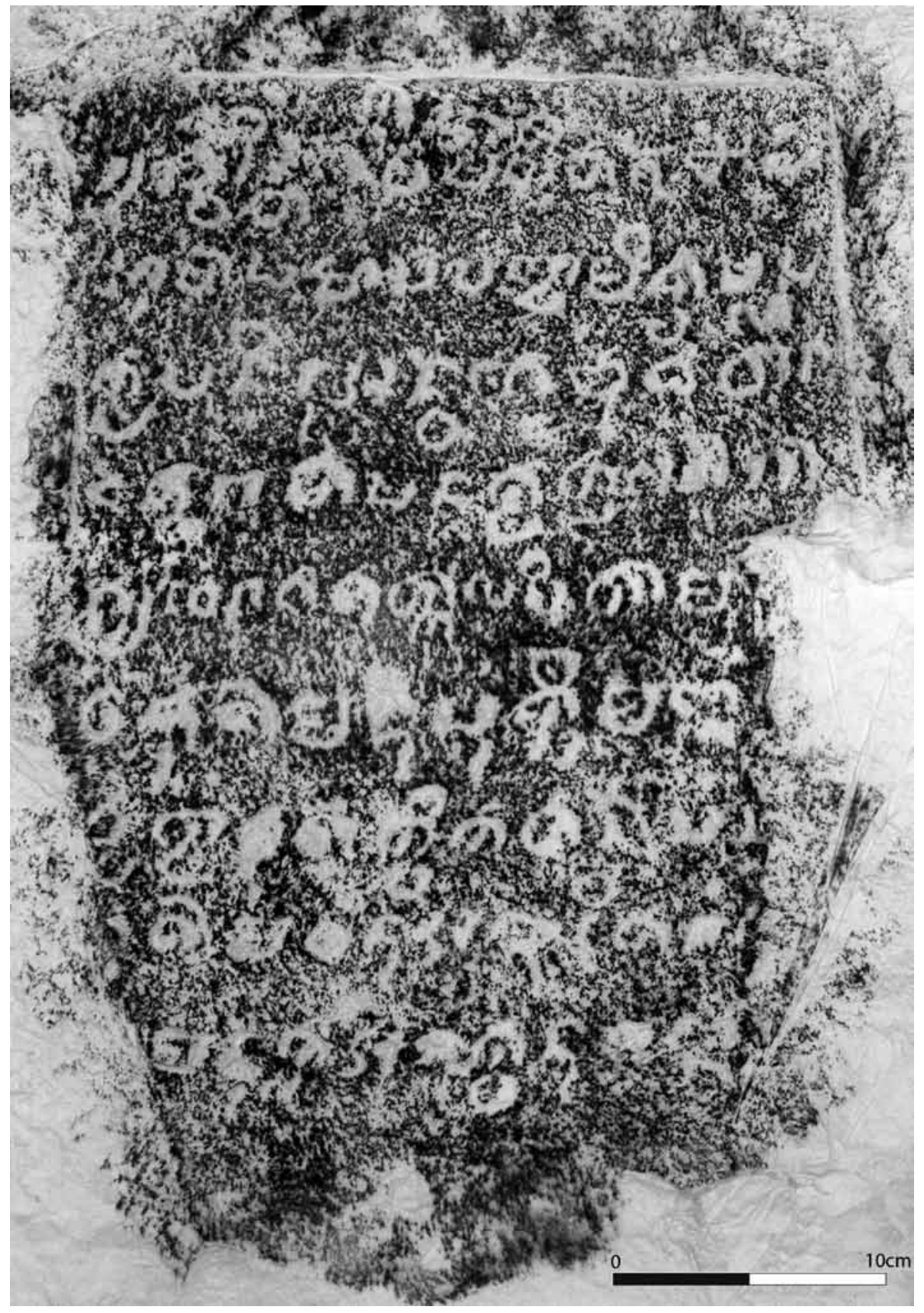

Figure 10. Wangkud inscription. EFEO estampage n. 2038. 


\section{Ruined stela inscription}

A stela prepared in very rough composite stone, whose inscribed surface is in terribly bad condition so that the text is indecipherable, bears inventory number 04.0545. It was found in desa Gajihan, kecamatan Gunungwungkal, kabupaten Pati.

\section{Block of stone with geometric decoration (Figures 11 and 12)}

The block of stone bearing the inventory number 04.0569 is of unknown provenance. It seems as though this block may have served as pedestal for a sculpture. If such was indeed the case, the two or three lines of text that are discernible on the upper surface of the stone would have been invisible after mounting of the sculpture. The text is very hard to read, but the name of Ganapati, a god typically invoked at the beginning of any undertaking, is discernible and so is the word idam, which proves the languages was Sanskrit. The third line clearly shows signs, but I do not recognize any akșaras here.

(1) ${ }^{\circ}$ om ganapati xx pāla bhra $\ldots$

(2) ma x jaḥ rāja(bh/g)ṛ x m idam· ।

(3) ...

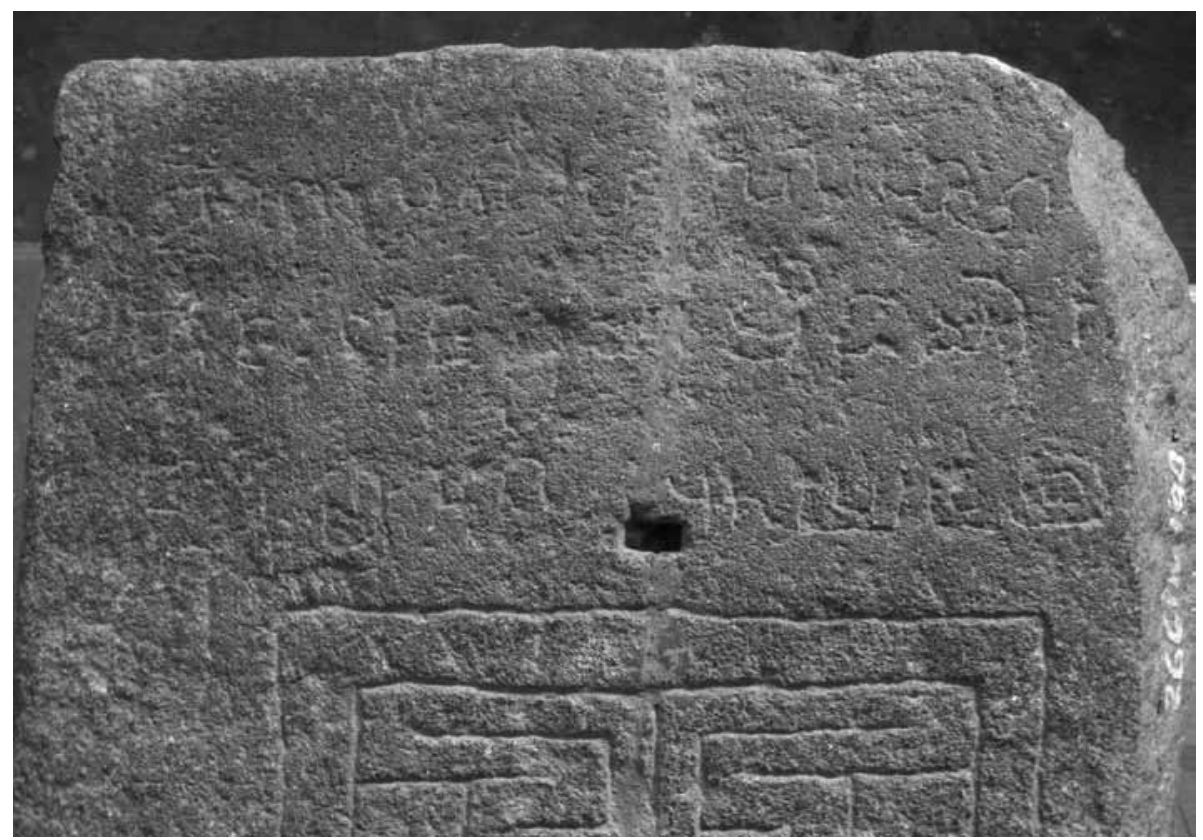

Figure 11. MRS 04.0569. Inscription on stone with geometric decoration. Photo Arlo Griffiths. 


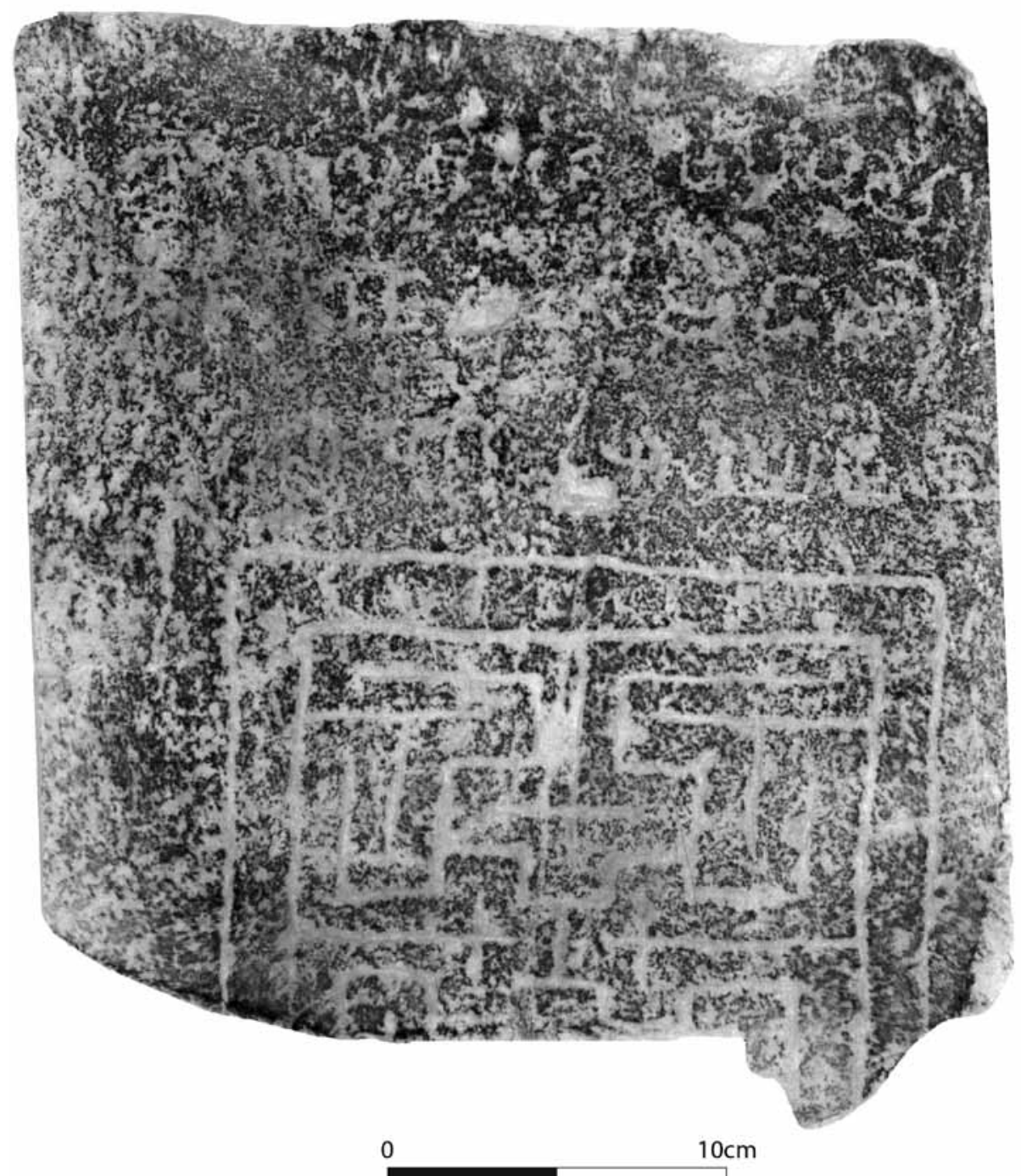

Figure 12. Inscription on stone with geometric decoration. EFEO estampage n. 2037.

Inscriptions on bronze artefacts

The museum holds two bronze-plate inscriptions (without inventory numbers). One of them is in nearly perfect condition, and is inscribed on only one face; the other, inscribed on both faces, is severely damaged, having been broken into pieces, of which only two now remain, with loss of a substantial part (about 1/4) of the text. The well-preserved inscription was published in 1982 as 
the 'Luitan inscription' by Nastiti et al., who have (p. 5) given various pieces of information about the place and circumstances of its discovery together with the fragments of the plate inscribed on both faces. This second plate, which remains unpublished, consists entirely of a list of names of functionaries and gifts they received. It contains no date. Nastiti et al. rightly point out that the script on both plates is not the same, but that they must nevertheless date to the same period, for they share the names of several functionaries.

The museum further holds a magnificent bronze sculpture (inv. nr. 04.2321) of a Buddha seated with pedant legs (bhadrāsana) on a throne whose back is inscribed with three lines of text in Eastern Indian Siddhamātrkā script. This sculpture and its inscription will form the object of a separate study by Nicolas Revire, Rajat Sanyal and myself.

\section{Inscriptions on gold artefacts}

The museum holds six gold artefacts with inscriptions. Provenances are recorded for several of them, which is a rare luxury in the study of Indonesian gold artefacts.

\section{Gold foil (Figure 13)}

A small piece of gold foil, measuring $2,7 \times 2 \mathrm{~cm}$ and bearing inventory number 04.1011, was according to the museum's registration card recovered from desa Girirejo, kecamatan Tegak, kabupaten Magelang. ${ }^{20}$ Its reading is as follows:

(1) ${ }^{\circ}$ om ${ }^{\circ} \mathrm{e}^{\circ} \mathrm{om}{ }^{\circ}$ ai

(2) sah ${ }^{\circ}$ om jūjūu

(3) sah

This is a mantra, possibly from a Śaiva context. The final bit, on lines 2-3, looks like a variant of the Mrtyuñjayamantra, om jum sah, taught, among other texts, in the Netratantra, ${ }^{21}$ where it is elevated to the status of an all-purpose Mantra that can be used in the worship of any deity, whether Śaiva or not, and in the Śāradātilaka. ${ }^{22}$

20 The registration card is probably in error here, for Véronique Degroot points out to me that there is no kec. Tegak in kab. Magelang.

21 On the nature and date of this text, see Sanderson 2005:239-70. The passage in question is Netratantra 2.21-28ab, which is difficult to decode even with the aid of Kșemarāja's commentary. I owe the reference to Dominic Goodall. The edition I have used is that by Shāstrī 1926-39.

22 On the nature and date of this text, see Sanderson 2007:230-3. The passage in question is Śāradātilaka 18.105-129. I owe this reference to Alexis Sanderson. The edition I have used is that by Avalon 1996. Sanderson has also provided a number of references to unpublished Sanskrit texts teaching the same mantra. 


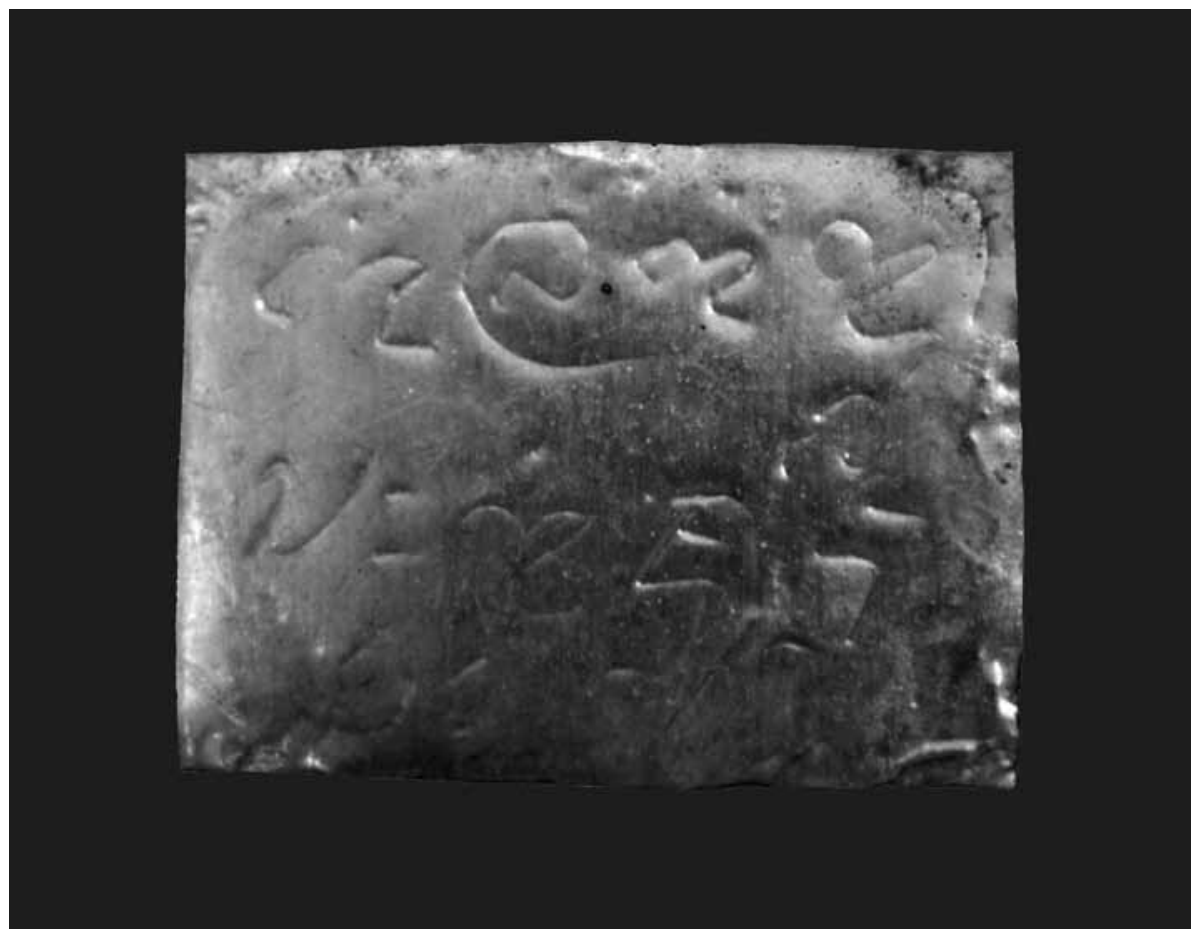

Figure 13. MRS 04.1101. Inscription on gold foil. Photo Arlo Griffiths.

\section{Five signet rings (Figures 14-18)}

The museum holds a small number of signet rings showing 'imitation' Nāgarī texts of the type seen quite commonly in collections of ancient Javanese rings (compare Miksic 2011:153). The imitated 'texts' we see on such rings do not constitute writing and can hence not be defined as inscriptions. The museum also holds several more or less stylized cases of the common śri symbol engraved in the positive, which we shall here also leave out of consideration (compare on this type of ring, Bosch 1927; Miksic 2011:153-5). The museum further holds five rings inscribed with writing in the negative, evidently intended to be used as seals. I am preparing a comprehensive study of all known examples of this type of Old Javanese signet rings with negative writing, so will limit myself here to publishing the readings of the rings at $\mathrm{Mu}-$ seum Ranggawarsita with their respective provenances recorded in the $\mathrm{Mu}-$ seum, and some notes on the meanings of the inscribed texts. 


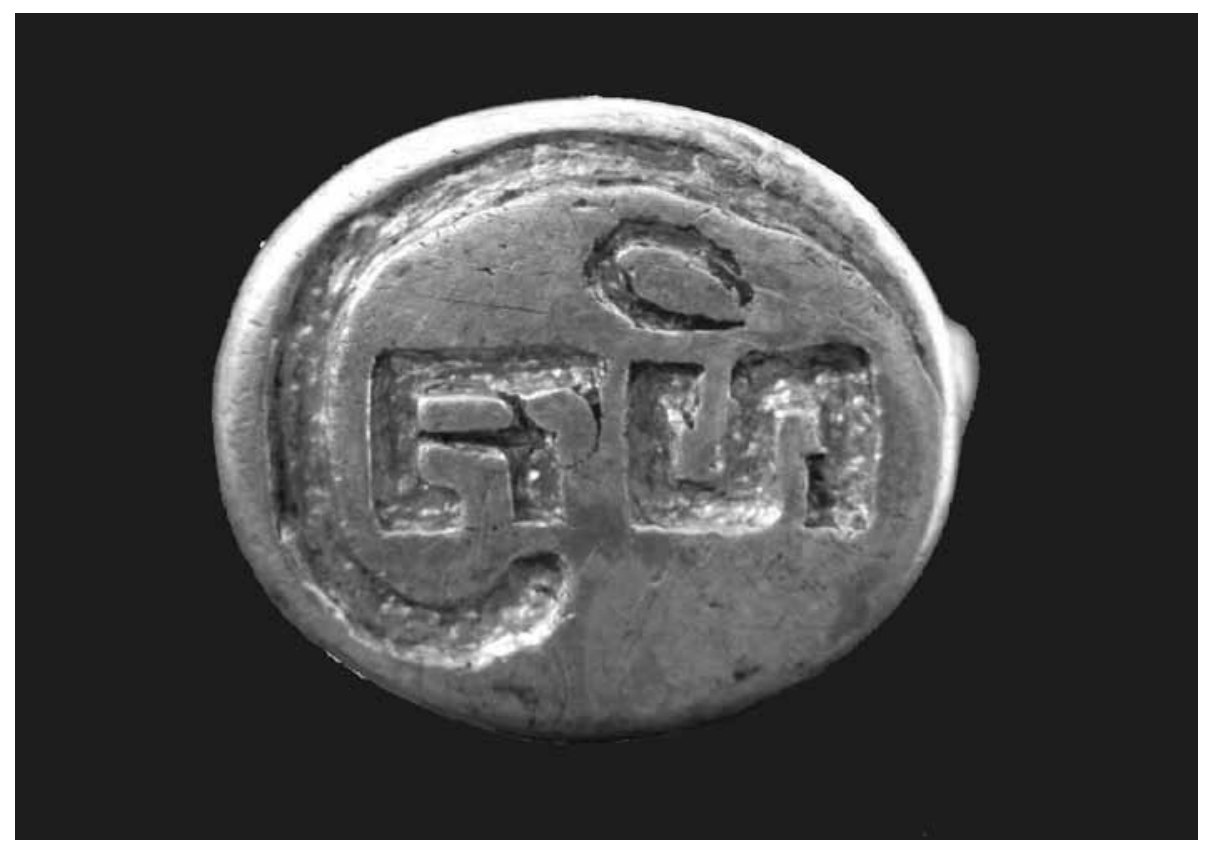

Figure 14. MRS 04.1014. Inscribed signet ring. Photo Arlo Griffiths, inverted horizontally.

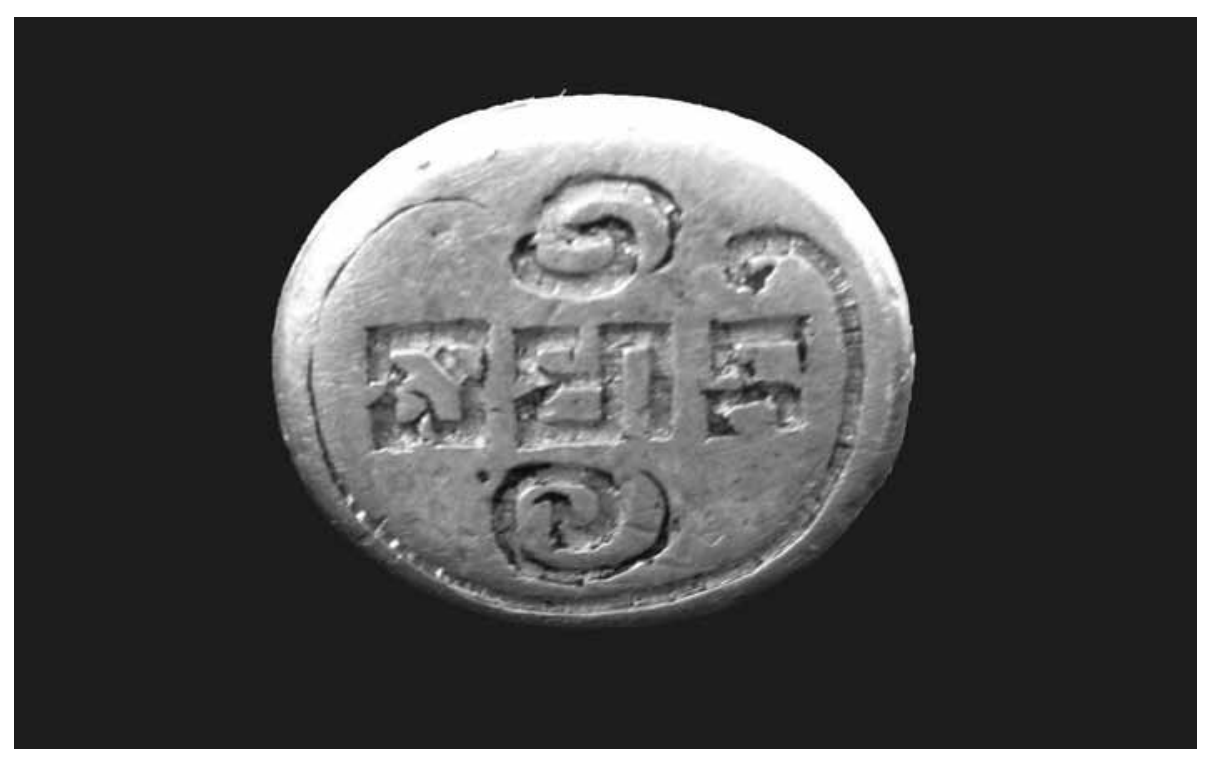

Figure 15. MRS 04.1015. Inscribed signet ring. Photo Arlo Griffiths, inverted horizontally. 


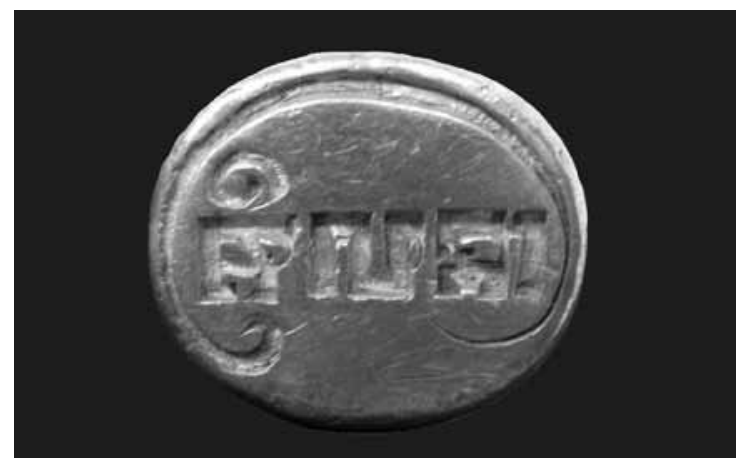

Figure 16. MRS 04.1016. Inscribed signet ring. Photo Arlo Griffiths, inverted horizontally.

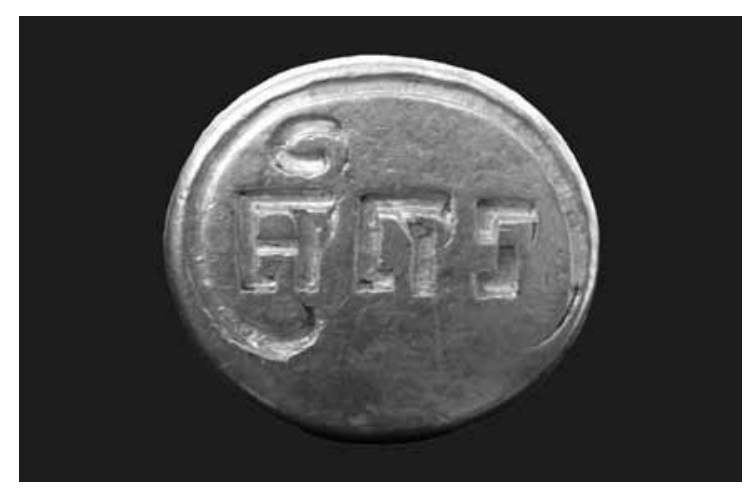

Figure 17. MRS 04.1017. Inscribed signet ring. Photo Arlo Griffiths, inverted horizontally.

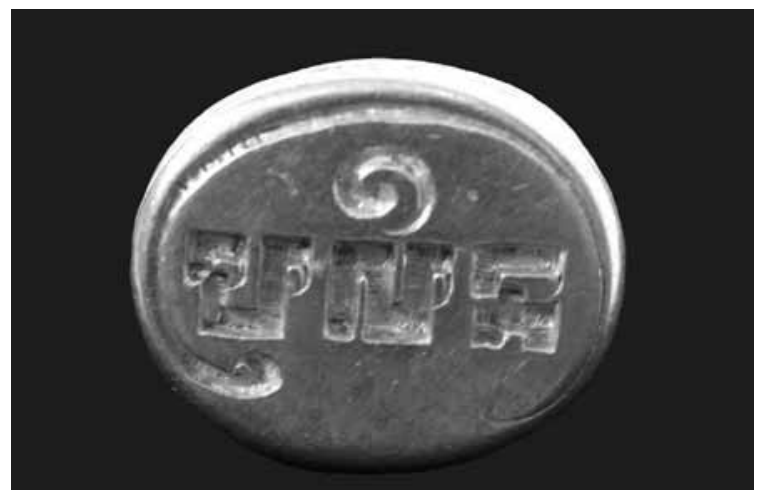

Figure 18. MRS 04.1018. Inscribed signet ring. Photo Arlo Griffiths, inverted horizontally. 
- inv. nr. 04.1014, from desa Pagerdawung, kecamatan Gemuh, kabupaten Kendal: śrahi. I do not know any other ancient Javanese signet ring on which this sequence of aksaras is engraved, and think we are dealing with a text that is a wrongly executed and incomplete version of the very commonly found signet-ring text śrì hana.

- inv. nr. 04.1015, from desa Gandrungmanis, kecamatan Gandrungmangu, kabupaten Cilacap: dharmmān. This could be a passive irrealis of the base $\operatorname{dharm}(m) a$, used as verb in the meaning 'to give', in which case it would probably something like 'may it be given'; perhaps more likely, the form is a nominal derivation in -an, yielding the simple meaning ' gift'. $^{\prime}$

- inv. nr. 04.1016, from desa Pagerdawung, kecamatan Gemuh, kabupaten Kendal: śrillanā. I think the engraver has here made an error caused by the fact that he was writing in the negative and that la is precisely the mirror image of $h a$, so that the intended text was probably śri hanā. I see in this example support for my interpretation of the much more commonly found spelling hana as a non-overtly marked irrealis form (with suffix $-a$ ), so that the whole corresponds to a putative Sanskrit model śrìr astu 'let there be fortune' (found a such in several inscriptions).

- inv. nr. 04.1017, from desa Gandrungmanis, kecamatan Gandrungmangu, kabupaten Cilacap: śrīgara. I again hypothesize an error caused by confusion between positive/negative writing (here $b h a / g a$ ), and tentatively propose to understand śrībhara, known as royal epithet in India, meaning 'endowed with fortune'.

- inv. nr. 04.1018, from desa Gandrungmanis, kecamatan Gandrungmangu, kabupaten Cilacap: pralina. This is another text found on several other known signet rings from ancient Java. It seems to mean something like 'deceased' or 'invalid'. I do not know any convincing explanation for why this would have been in common use as text to be used on seals made of gold whose users must have been limited to the ancient Javanese elite.

Besides several small misreadings, there is a more serious problem in the $\mathrm{Mu}-$ seum's registration cards for four of these items, where there is a mismatch between the photos of the rings pasted on the cards, and the readings attributed to them. The card showing 04.1015 dharmmān is provided with the reading 'srilata'; the card showing 04.1016 śrilanā is provided with the reading 'srigara' corrected to 'srigrha'; the card showing 04.1017 śrigara is provided with the reading 'pralina'; the card showing 04.1018 pralina is provided with the reading 'dharmana'. I have not been able to ascertain whether it can be excluded that the mismatch is indeed only between attributed readings and the other data (including photos); in other words, there may also be a regrettable mismatch between inventory numbers, rings, and provenances. So to be prudent, for further research the most we can be sure of is the fact that 
we have two provenances for these five rings, but we do not know precisely which ring came from where. ${ }^{23}$

\section{Conclusion}

Museum Ranggawarsita in Semarang holds a valuable and diverse collection of inscribed artefacts, generally well preserved and with relatively ample documentation of provenances. It would be advisable for the competent authorities to develop this museum as a safe storage point for other inscriptions, already known or to be discovered in the future, and to act against the trend noticeable throughout the provinces of Jawa Tengah and Jawa Timur towards multiplication of decentralized collections, which goes hand in hand with a decrease in security and quality of documentation of the artefacts in question, and hence of their use to scholarship.

The most outstanding feature of the epigraphical collection is that it assembles three of the seven known inscriptions from the Batang region of Java's north coast. The importance of the north coast, and particularly the access from Batang to the ancient temple complex on the Dieng plateau, has been highlighted in the important study of Van der Meulen (1977). But this study, based mainly on (non-epigraphical) written sources, and essentially an engagement with Chinese documents, needs to be reevaluated in the light of archaeological surveys undertaken in the 1970s (Satari et al. 1977; Satari 1978), and subsequently (Baskoro Daru Tjahjono 2000), and of course in the light of the inscriptions that have since become known.

A recent article (Noerwidi 2007) builds on the mentioned archaeological surveys (while ignoring Van der Meulen) and for the first time explicitly focuses on the Batang regency as a pivotal region in the earliest history of Central Java. The inscriptions of the Batang area are elaborately referred to, but one notices how much the absence of reliable readings, or any readings at all, becomes an impetus for long discussions without any basis in fact. It is hoped that the publication of the inscriptions of Batang regency in this article may serve as a reliable basis for future research in the ancient history of Java's north coast. In this connection, the discovery of the remarkable similarity between the Balekambang inscription (from Batang regency) and that of Hampran/Plumpungan (in situ near Salatiga), which must indicate some form of cultural affinity between the two areas, is perhaps the most fascinating result presented here.

23 According to the official website of kabupaten Kendal, Pagerdawung today falls under kecamatan Ringinarum. See http://www.kendalkab.go.id/index.php/kecamatan/kecamatan-ringinarum/ 1738-ringinarum (accessed 19 April 2012). 


\section{References}

Atmodjo, M.M. Sukarto K.

1985 'Prasasti Sipater dan prasasti Wangkud', in: Satyawati Suleiman (ed.), Rapat evaluasi hasil penelitian arkeologi ke-2, Cisarua, 5-10 Maret 1984, pp. 229-40. Jakarta: Pusat Penelitian Arkeologi Nasional.

Avalon, Arthur 'Beberapa temuan prasasti baru di Indonesia', in: Berkala Arkeologi (Yogyakarta) 14 [Edisi khusus: Evaluasi Sejarah dan Interpretasi baru Sejarah Indonesia Kuno (Dalam Rangka Purna Bhakti Drs. M.M. Soekarto Karto Atmojo) Yogyakarta 23-24 Maret 1994], 1-5.

1996 Śāradātilaka Tantram: Text with introduction. Delhi: Motilal Banarsidass.

Baskoro Daru Tjahjono

2000 Budaya marginal masa klasik di Jawa Tengah. Balai Arkeologi Yogyakarta. [Berita Penelitian Arkeologi 12.]

Bhattacharya, Gouriswar

1977 'Nandin and Vṛsabha', in: Wolfgang Voigt (ed.), XIX. Deutscher Orientalistentag: Vom 28. September bis 4. Oktober 1975 in Freiburg im Breisgau: Vorträge, pp. 1545-67. Wiesbaden: Steiner. [Zeitschrift der Deutschen Morgenländischen Gesellschaft, Supplement III, 2.]

2000 Essays on Buddhist, Hindu, Jain iconography $\mathcal{E}$ epigraphy. Editor Enamul Haque. Dhaka: International Centre for Study of Bengal Art. [Studies in

Boechari Bengal Art Series 1.]

1966

'Preliminary report on the discovery of an Old-Malay inscription at SoBosch, F.D.K. djomerto', Madjalah Ilmu-Ilmu Sastra Indonesia 3-2/3:241-51.

1927

'Gouden vingerringen uit het Hindoe-Javaansche tijdperk', Djåwå 7:30520.

Brandes, J.L.A.

1913 Oud-Javaansche oorkonden: Nagelaten transscripties van wijlen J.L.A. Brandes. Uitgegeven door N.J. Krom. Batavia: Albrecht, 's-Hage: Nijhoff. [Verhandelingen van het Bataviaasch Genootschap van Kunsten en We-

Damais, Louis-Charles tenschappen 60.]

1951 'Etudes d'épigraphie indonésienne. I: Méthode de réduction des dates javanaises en dates européennes', Bulletin de l'École française d'ExtrêmeOrient 45-1:1-41.

1952 'Etudes d'épigraphie indonésienne. III: Liste des principales inscriptions datées de l'Indonésie', Bulletin de l'École française d’Extrême-Orient 46-1:1105.

'Etudes d'épigraphie indonésienne. IV: Discussion de la date des inscriptions', Bulletin de l'École française d'Extrême-Orient 47-1:7-290. 'Bibliographie indonésienne XI. Les publications épigraphiques du service archéologique de l'Indonésie', Bulletin de l'École française d'ExtrêmeOrient 54:295-521. Répertoire onomastique de l'épigraphie javanaise jusqu'à Pu Sindok Śrī Iśānawikrama Dharmmottungadewa. Paris: École française d'Extrême-Orient. 
Degroot, Véronique

2009 Candi, space and landscape: A study on the distribution, orientation and spatial organization of Central Javanese temple remains. Leiden: Sidestone Press.

[Mededelingen van het Rijksmuseum voor Volkenkunde Leiden 38.]

Goodall, Dominic et al.

2004 The Pañcāvaranastava of Aghoraśiva: A twelfth-century South Indian prescription for the visualisation of Sadassiva and his retinue. Pondicherry: Institut Griffiths, Arlo français de Pondichéry/École française d'Extrême-Orient.

2009 'Sūrya's Nāgas, Candra's square seat and the mounted bull with two guardians: Iconigraphical notes on two Khmer illustrated stela inscriptions', in: Gerd J.R. Mevissen and Arundhati Banerjee (eds), Prajūādhara: Essays on Indian arts, history, epigraphy and culture in honour of Gouriswar Bhattacharya, pp. 466-78. New Delhi: Kaveri Books.

Hermawati and YM. Kussunartini

1998-99 Arca Perunggu Koleksi Museum Negeri Provinsi Jawa Tengah Ronggowarsito. Semarang. [Diterbitkan tahun anggaran 2000.]

Krom, N.J.

1924 'Over het Çivaisme van Midden-Java', Mededeelingen der Koninklijke Akademie van Wetenschappen 58:199-225. [Afdeeling Letterkunde, Serie B.]

Meulen, W.J. van der

1977 'In search of "Ho-Ling"', Indonesia 23:87-111.

Miksic, John

2011 Old Javanese gold: The Hunter Thompson Collection at the Yale University Art Gallery. Second revised and expanded edition. New Haven, CT: Yale University Press. [First edition 1990.]

\section{Nakada, Kōzō}

1982 An inventory of the dated inscriptions in Java. Tokyo: Toyo Bunko.

1986 'The Munduan copper-plate inscriptions found in Java [in Japanese]', Nantoh Shigaku (Journal of Ryukyuan Studies) 28:1-21.

Nastiti, Titi Surti, Dyah Wijaya Dewi and Richadiana Kartakusuma

1982 Tiga prasasti dari masa Balitung. Jakarta: Proyek Penelitian Purbakala, Departemen P dan K. [Pusat Penelitian Arkeologi Nasional.]

Noerwidi, Sofwan

2007 'Melacak jejak awal indianisasi di pantai utara Jawatengah', Berkala Arkeologi 27-2:54-87. http://arkeologijawa2.files.wordpress.com/2009/10/05_ sofwan.pdf (accessed March 2012).

Nugrahani, D.S., Slamet Pinardi, Rusmulia Tjiptadi H. and Gutomo

1998 Katelog artefak temuan Rejoso 1997. Prambanan: Suaka Peninggalan Seja-

Poerbatjaraka, R.Ng. rah dan Purbakala Provinsi Jawa Tengah.

1932 'Het Oud-Javaansche Rāmāyaṇa', Tijdschrift voor Indische Taal-, Land- en Volkenkunde (TBG) 72:151-214.

Sanderson, Alexis

2003-04 'The Śaiva religion among the Khmers, Part I', Bulletin de l'École française d'Extrême-Orient 90-91:349-462.

2004 'Religion and the state: Śaiva officiants in the territory of the king's brahmanical chaplain', Indo-Iranian Journal 47:229-300. [Appeared 2005.] 

Paippalādins and their connection with the Trika and the Kālīkula. With critical editions of the Parājapavidhi, the Parāmantravidhi, and the *Bhadrakālìmantravidhiprakarana', in: A. Griffiths and A. Schmiedchen (eds), The Atharvaveda and its Paippalādaśäkhā: Historical and philological papers on a Vedic tradition, pp. 195-311. Aachen: Shaker.

Sarkar, Himansu Bhusan

1972 Corpus of the inscriptions of Java (Corpus inscriptionum Javanicarum), (up to Satari, Sujatmi 928 A.D.). Vol. 2. Calcutta: Mukopadhyay.

1978 New finds in northern Central Java. Jakarta: Pusat Penelitian Purbakala dan Peninggalan Nasional. [Berita Pusat Penelitian Purbakala dan Peninggalan Nasional 13.] [Reprinted in Capita Selecta Bulletin of the National Research Centre of Archaeology of Indonesia, Jakarta: Pusat Penelitian dan Pengembangan Arkeologi Nasional, 2008, pp. 83-99.]

Satari, Soejatmi, Ribut Darmosoetopo, Agung Sukardjo, R.M Soesanto

1977 Laporan hasil survai kepurbakalaan di daerah Jawa Tengah bagian utara kabupaten Pekalongan, Batang dan Kendal. Jakarta: Proyek Pengembangan Media Kebudayaan, Departemen Pendidikan dan Kebudayaan. [Berita Penelitian Arkeologi 9.]

Shāstrī, Madhusūdan Kaul

1926-39 The Netra Tantram. With commentary by Kshemarāja. [Bombay]: Śrīnagara. Two vols. [Kashmir Series of Texts and Studies 46, 61.]

Suhadi, Machi and M.M. Soekarto

1986 Laporan penelitian epigrafi Jawa Tengah. Jakarta: Proyek Penelitian Purbakala, Departemen Pendidikan dan Kebudayaan. [Berita Penelitian Arkeologi 37.]

Sundberg, Jeffrey Roger

2004 'The wilderness monks of the Abhayagirivihāra and the origins of SinoJavanese esoteric Buddhism', Bijdragen tot de Taal-, Land-en Volkenkunde 160:95-123. 